\title{
SOCIO-ECONOMIC AND DEMOGRAPHIC DETERMINANTS OF WOMEN PARTICIPATION IN LABOR FORCE IN RURAL BANGLADESH
}

\author{
SACCHIDANAND MAJUMDER* ${ }^{1}$ AND SOMA DEY ${ }^{2}$ \\ ${ }^{1}$ Department of Statistics, University of Chittagong, Bangladesh \\ ${ }^{2}$ Faculty of Business Administration, BGC Trust University Bangladesh, \\ BGC Biddyanagar, Chandanaish, Chittagong, Bangladesh
}

\begin{abstract}
This attempt was made to investigate the socio-economic and demographic factors that influence women participation in labor force in rural Bangladesh using BDHS 2014 data. A total of 11,695 married women aged 15 - 49 in rural areas are selected for analysis. A logistic regression analysis is applied for determining the factors. The result shows that $32.2 \%$ rural women are currently employed and the remaining $67.8 \%$ are unemployed. The logistic model shows that women's age has a strong positive association with their participation in labor force. Participation of widowed and divorced/separated women in labor force is much higher as compared to married women. Enhanced education level of women and their husband has decreased women participation in labor force, but it gradually increased with increased education level of household head. Husband's occupation is a strong determinant of women participation in labor force. Women from middle income households are less interested to participate in labor force as compared to poor women. The result also reveals that with increased household size and number of children under age five, women participation in labor force is decreased. Again, with increased land and livestock ownership of household and NGO membership, women participation in labor force is highly increased.
\end{abstract}

Key words: Socio-economic determinants, Women participation, Logistic regression analysis

\section{Introduction}

In developing economies, women play an important role by contributing to household income, adding to the supply of labor for economic activities, and above all by empowering women (Rahman 2013).Women participation in labor force significantly contributes to socio-economic development because of a second source of household income and can help to reduce poverty. Women's employment is a critical factor in their progression towards economic independence and is considered as an indicator of their overall status in society (Mammen and Paxson 2008). Presently, women participation in labor force has become an essential element in the determination of the performance of economic development, both in Developed and in Developing countries (Che and Sundjo 2018).

*Corresponding author: mithu.m2011@gmail.com 
In the Population and Housing Census 2011, it is mentioned that women constitute half in the population composition of Bangladesh and play a very significant role in the economy (BBS 2012). Bangladesh is a developing country in South Asian region with 161.3 million of total population, of which 80.3 million are female. Among the total population, 109.1 million are of age 15 or older which is $67.6 \%$ of total population, of whom 55.0 million $(50.4 \%)$ are female. In rural areas, the total population of age 15 or older is 77.1 million (29.3\%) (BBS 2018). In 2016-2017, the employment rate of rural women of age 15 and over is $36.3 \%$ and it was $36.0 \%$ in $2010,33.5 \%$ in 2013 and $35.6 \%$ in 2015-2016 (BBS 2018).

Women participation in labor force is influenced by a wide range of factors with socioeconomic and demographic factors. Several studies found that women's age has positive significant effect on participation in labor force (Roy et al. 2015, Lisaniler and Bhatti 2005, Amin 1994). In contrary, another study mentioned that younger women (aged 1524), are less likely to participate in the labor market (Faridi et al. 2009). Women's age is inversely related to participation rate in labor force in Kuwait (Aly and Quisi 1996).

Household size has a negative effect on women participation in labor force (Babalola and Akor 2013).Women who have a smaller family are more likely to engage in paid work and revealed that the number of children below age five has an insignificant impact on women employment in Bangladesh (Amin 2005). The number of children is positively significant with the women participation in labor force (Mincer 1962, Faridi et al. 2009) but, women with children aged 0-6 are less likely to participate in the labor market (Faridi et al. 2009). Several studies found that the number of children is inversely related with women participation in labor force (Aly and Quisi 1996, Maglad 1998, Sackey 2005). In Bangladesh, another study mentioned that having infants have a negative impact on women participation in labor force (Rahman 2006).

Women participation in labor force is strongly influenced by marital status (Grantham 2012). Divorced women are the most likely to seek employment, followed by married women, and lastly single women; reason being that these divorced women have little or no prospects of economic dependence (Mlatsheni and Leibbrandt 2001). Several studies found that marital status is positively related to women participation in labor force (Amin 1994, Faridi et al. 2009). In contrary, several other studies implied that marital status is inversely related with women labor force participation rate (Aly and Quisi 1996, Rahman 2006). Female headed household have a positive impact on the women participation in labor force (Amin 2005, Rahman 2006), but the household having educated household head have a negative impact on women participation in labor force (Rahman 2006). 
Women tend to take part in the labor market more with higher levels of education. There is a stronger tendency for a more educated woman to remain economically active than a less educated woman (Oluwasey 2013). Another study showed that in Bangladesh, female with higher education have a positive impact on participation in labor force and low level of education has a negative impact on the female participant in labor market (Rahman 2006). Female literacy rates are important determinants of rural female work participation rates in the different districts of the rural areas of North Bengal region of the state of West Bengal in India (Rai 2017). Several studies also found that female education has positive impact on the women participation in labor force (Aly and Quisi 1996, Maglad 1998, Sackey 2005, Atieno 2006, Bbaale and Mpuga 2011, Babalola and Akor 2013). However, Roy et al. (2015) observed that education is negatively associated with women participation in labor force.

Women participation in labor force is strongly influenced by the occupation of the husband (Grantham 2012). A man with higher earnings through a higher level of education and occupation will prefer his wife to reduce her participation in labor force and to focus more on housework (Devereux 2004, Kalenkoski et al. 2009). A study portrayed that women whose husbands are economically active, are less likely to participate in the labor market (Faridi et al. 2009). Another study found that husband employment status has a negative effect on women participation in labor force (Babalola and Akor 2013).

Land holding, and husband's assets have negative effects on women participation in labor force (Khandker 1987). Land ownership has a negative impact on women participation in labor force and the rapid expansion of micro finance in rural areas has supported women's employment in poultry and livestock (Rahman 2006). Another study illustrated that home-based economic activities has pushed the women labor force participation in Bangladesh (Amin 2005). A study found that women participation in labor force is negatively related to asset ownership (Maglad 1998). On the other hand lower levels of household wealth and microcredit have a positive impact on women participation in labor force (Amin 2005).

Social factor, especially religion has tremendous effects on women participation in labor force. Several authors found that different religions have an influence on economic attitudes and women participation in labor force (Chadwick and Brent 1993, Guiso et al. 2003). In Nigeria, a study revealed that factors such as marital status, religion, and poverty rate were the significant determinants of female participation in labor force in the rural area (Iweagu et al. 2015). 
The above discussed literature clearly shows that various factors have an important effect on women participation in labor force. Rural women's primary asset is their own labor, therefore one of the keys onto achieving the Sustainable Development Goals (SDGs), is to ensure more and better rural employment whether waged or self-employed enterprise (Fontana and Paciello 2010). This study is significant in that, it is tried to find out various important socio-economic and demographic factors which are significantly associated with women participation in labor force. So that, this study serves as an important contribution to make decision to increase women participation and development. The aim of this study is to investigate socio-economic and demographic factors that influence women participation in labor force in rural Bangladesh.

\section{Materials and Methods}

Data source: The data analyzed in this study are sourced from Demographic and Health Surveys (DHS) 2014 for Bangladesh under the authority of the National Institute of Population Research and Training (NIPORT), Ministry of Health and Family Welfare and implemented by Mitra and Associates, Dhaka. The dataset are available online at https://dhsprogram.com/data/available-datasets.cfm. The survey covered both rural and urban populations. The survey collected information relating to demographic and detailed information on asset ownership, access to public services and housing characteristics (BDHS 2014).

Sample size: The Bangladesh DHS, 2014 was based on a two-stage stratified sample of households. In the first stage, 600 Enumeration Areas (EAs) were selected with probability proportional to the EA size, with 207 clusters in urban areas and 393 in rural areas. A complete household listing operation was then carried out in all the selected EAs to provide a sampling frame for the second-stage selection of households. In the second stage of sampling, a systematic sample of 30 households on average was selected per EA to provide statistically reliable estimates of key demographic and health variables for the country as a whole, for urban and rural areas separately, and for each of the seven divisions. With this design, the survey selected 18,000 residential households to conduct the survey. Finally, 17,300 households (Urban: 5,930 and Rural: 11,370) were surveyed. In the BDHS, 2014, a total of 17,863 married women (urban: 6,167 and rural: 11,696) aged 15-49 were interviewed from 14,997 households out of 17,300 surveyed households (BDHS 2014). In this study, 11,695 married women aged 15-49 instead of total interviewed women 11,696 in rural areas are selected for analysis because of some missing observations of the selected variables in the study. 
Variables: Women participation in labor force as dependent variable is measured based on individual question about current working status with two categories, employed and unemployed. So, to create the binary variable women participation in labor force, $1=$ yes, if woman is currently employed and $0=$ no, if woman is currently unemployed.

After reviewing some research paper related to women participation in labor force, some explanatory variables are included in the study to determinant the factor influencing women participation in labor force. The explanatory variables are women's age, women's education, women's marital status, age of household head, sex of household head, education level of household head, husband's education level, husband's occupation, household size, number of children under 5, wealth index, land ownership of household, livestock ownership of household, media exposure, NGO membership, and religion.

Methodologies: Bivariate analysis: Bivariate analysis was conducted to verify whether there is any association between dependent and independent variables. Chi-square test of independence is used to examine the effect of socio-economic and demographic characteristics on women participation in labor force. To identify the factors most strongly associated with it, the entre method of logistic regression model is performed.

Logistic regression analysis: The analysis uses logistic regression, which estimates model with a binary response and a set of explanatory variables. In logistic regression model, a dichotomous variable, women participation in labor force is introduced to determine whether woman is employed or not.

Here,

Women participation in labor force $= \begin{cases}0, & \text { if women is unemployed } \\ 1, & \text { if women is employed }\end{cases}$

The logistic regression model is given by

$$
\operatorname{logit}\left(P_{i}\right)=\log \left(\frac{P_{i}}{1-P_{i}}\right)=\sum_{i} \beta_{i} X_{i}
$$

where,

$$
P_{i}=P\left(Y_{i=} \frac{1}{X_{i}}\right)=\frac{\exp \left(\sum \beta_{i} X_{i}\right)}{1+\exp \left(\sum \beta_{i} X_{i}\right)}=\text { Probability that the } \mathrm{i}^{\text {th }} \text { woman is employed }
$$

$\mathrm{Y}=$ Woman participation status in labor force of $\mathrm{i}^{\text {th }}$ woman;

$Y_{i}=1$ if woman is employed, and zero if woman is unemployed,

$\mathrm{X}_{\mathrm{i}}=\mathrm{i}^{\text {th }}$ predictor variable; and $\beta_{i}=\mathrm{i}^{\text {th }}$ parameter associated with $\mathrm{X}_{\mathrm{i}}$. 


\section{Results and Discussion}

All the analyses are performed by SPSS (V21.0). Information are obtained from 11,695 ever married rural women with current age of 15-49. Among these selected women, $3,762(32.2 \%)$ are currently employed and the remaining 7,933 (67.8\%) are unemployed. In 2016-2017, the employment rate of rural women age of 15 and over is 36.3\% (BBS 2018).

Bivariate analysis: In order to assess whether the covariates as significantly associated with women participantion in labor force or not, cross tabulation and Pearson Chi-square $\left(\chi^{2}\right)$ tests are performed first. Then those variables found to be significant in Chi-square test are used to construct logistic regression model.

The distribution of women by age and participation in labor force result shows that women who belong to age less than 35, 35-39, 40-44 and 45-49, about 28.7, 38.9, 39.2 and $37.3 \%$ are employed. In 2016-2017, the employment rate of rural women with age 15-24, 25-34, 35-44, 45-54, 55-64 and 65+ are 20.9, 44.0, 52.1, 44.7, 28.4 and 9.3\%, respectively (BBS 2018). About $31.3 \%$ currently married women, $44.7 \%$ widowed, and $55.1 \%$ divorced or separated women are employed. The result portrays that women who have no education, primary, secondary, and higher education, about 39.6, 33.5, 26.2 and $29.8 \%$ are employed respectively. In 2016-2017, 38.2, 39.0, 33.1, 27.7, 51.2 and 18.6\% rural women employed with no education, primary, secondary, tertiary and others education respectively (BBS 2018). It is also illustrated that the household's head who belongs to age less than 35, 35-44, 45-54, 55-59 and 60 and above, about 31.5, 36.6, 33.8, 29.2 and $25.3 \%$ women are employed. Further, women who are from male and femaleheaded household, about 32.1 and $32.3 \%$ women are employed. The result mentions that about 35.0, 31.7 and 29.3\% women are employed who have non-educated, primary educated, secondary and higher educated household's head, respectively. It is showed that women whose husband have no education, primary, and secondary and higher education, 38.7, 32.5 and $26.4 \%$ women are employed respectively. It is found that about $21.3,34.8,35.9,28.9$ and $24.1 \%$ women are employed whose husband's occupation is unemployed, farmer, labor, business or service and others. Further, 47.7, 43.8, 36.6 and $28.5 \%$ women are employed whose household size is 1, 2, 3, 4 and 5 and more, respectively. Furthermore, about 36.2, 30.2, 22.7 and 16.4\% women are employed who have no child, one child, 2 children, and 3 and more children aged under 5, respectively. The result also shows that women who belong to poor, middle income, and rich family, about $64.2,68.8$ and $73.3 \%$ are unemployed, respectively. It is observed that in respect of land ownership the household who have no land ownership, less than 1 acre, and 1 acre 
and more, among these, 67.2, 66.2 and $71.6 \%$ women are unemployed, respectively. The households who have no livestock, $21.4 \%$ women are employed and $34.7 \%$ women are employed whose family has own livestock. It is found that women who expose to media and are not expose to media, 68.1 and $67.5 \%$ women are unemployed respectively. The study also mentions that women who have not NGO membership and have NGO membership, 27.9 and $40.5 \%$ women are employed, respectively. Finally, 68.7\% muslim and $59.3 \%$ non-muslim women are unemployed.

The result of Pearson $\chi^{2}$ tests displays in the Table 1 that all the independent variables except sex of household head and media exposure shows unadjusted significant $(p<0.001)$ association with women participation in labor force. Then, the logistic regression model is constructed using all these significant variables.

Table 1. Value of Pearson's $\chi^{2}$ statistics on cross-classifying selected predictors with women participation in labor force.

\begin{tabular}{lccc}
\hline Variables & Value of Pearson's $\chi^{2}$ & df & p value \\
\hline Age of women & 118.006 & 3 & 0.000 \\
Marital status of women & 85.876 & 2 & 0.000 \\
Educational level of women & 153.45 & 3 & 0.000 \\
Age of household head & 78.491 & 4 & 0.000 \\
Sex of household head & 0.019 & 1 & 0.891 \\
Educational level of household head & 30.889 & 2 & 0.000 \\
Educational level of husband & 140.078 & 2 & 0.000 \\
Occupation of husband & 80.393 & 4 & 0.000 \\
Household size & 119.941 & 3 & 0.000 \\
No. of children aged under 5 in household & 128.891 & 3 & 0.000 \\
Wealth index & 79.913 & 2 & 0.000 \\
Land ownership of household & 21.164 & 2 & 0.000 \\
Livestock ownership of household & 143.547 & 1 & 0.000 \\
Media exposure & 0.408 & 1 & 0.523 \\
NGO membership & 190.287 & 1 & 0.000 \\
Religion & 40.702 & 1 & 0.000 \\
\hline
\end{tabular}

Logistic regression analysis: For the study purpose, entre method of binary logistic regression analysis is performed. Using BDHS 2014 data, the logistic regression model is estimated to determine the factors affecting women participation in labor force in rural Bangladesh. The results of the fitted logistic regression model is displayed in the Table 2. 
Table 2. Results of logistic regression analysis with all independent variables.

\begin{tabular}{|c|c|c|c|c|c|c|c|}
\hline \multirow[t]{2}{*}{ Variables } & \multirow{2}{*}{$\begin{array}{l}\text { Coeffi- } \\
\text { cient }(\beta)\end{array}$} & \multirow{2}{*}{$\begin{array}{c}\text { Standard } \\
\text { error of } \\
\beta\end{array}$} & \multirow{2}{*}{$\begin{array}{l}\text { Degree of } \\
\text { freedom } \\
\text { (df) }\end{array}$} & \multirow[t]{2}{*}{$\mathrm{p}$ value } & \multirow{2}{*}{$\begin{array}{l}\text { Odd } \\
\text { ratio }\end{array}$} & \multicolumn{2}{|c|}{$\begin{array}{c}95 \% \text { C.I. for } \\
\text { odd ratio }\end{array}$} \\
\hline & & & & & & Lower & Upper \\
\hline \multicolumn{8}{|l|}{ Age of women } \\
\hline Aged less than 35 (RC) & & & 3 & 0.000 & 1.000 & & \\
\hline Aged $35-39$ & 0.245 & 0.067 & 1 & 0.000 & 1.277 & 1.120 & 1.457 \\
\hline Aged $40-44$ & 0.258 & 0.075 & 1 & 0.001 & 1.295 & 1.118 & 1.499 \\
\hline Aged $45-49$ & 0.249 & 0.082 & 1 & 0.003 & 1.283 & 1.091 & 1.507 \\
\hline \multicolumn{8}{|l|}{ Marital status of women } \\
\hline Married (RC) & & & 2 & 0.000 & 1.000 & & \\
\hline Widowed & 0.282 & 0.117 & 1 & 0.016 & 1.326 & 1.055 & 1.666 \\
\hline Divorced or separated & 0.966 & 0.145 & 1 & 0.000 & 2.629 & 1.979 & 3.491 \\
\hline \multicolumn{8}{|c|}{ Educational level of women } \\
\hline No education (RC) & & & 3 & 0.000 & 1.000 & & \\
\hline Primary & -0.185 & 0.057 & 1 & 0.001 & 0.831 & 0.743 & 0.930 \\
\hline Secondary & -0.291 & 0.068 & 1 & 0.000 & 0.748 & 0.655 & 0.854 \\
\hline Higher & 0.146 & 0.113 & 1 & 0.196 & 1.158 & 0.927 & 1.445 \\
\hline \multicolumn{8}{|l|}{ Age of household head } \\
\hline Aged less than 35 (RC) & & & 4 & 0.000 & 1.000 & & \\
\hline Aged $35-44$ & 0.139 & .061 & 1 & 0.023 & 1.149 & 1.019 & 1.296 \\
\hline Aged $45-54$ & -0.114 & .071 & 1 & 0.110 & 0.892 & 0.776 & 1.026 \\
\hline Aged $55-59$ & -0.243 & .093 & 1 & 0.009 & 0.784 & 0.654 & 0.940 \\
\hline Aged 60 and above & -0.271 & .078 & 1 & 0.001 & 0.762 & 0.654 & 0.889 \\
\hline \multicolumn{8}{|c|}{ Educational level of household head } \\
\hline No Education (RC) & & & 2 & 0.004 & 1.000 & & \\
\hline Primary & 0.038 & 0.075 & 1 & 0.614 & 1.039 & 0.896 & 1.204 \\
\hline Secondary and higher & 0.255 & 0.085 & 1 & 0.003 & 1.290 & 1.093 & 1.523 \\
\hline \multicolumn{8}{|c|}{ Educational level of husband } \\
\hline No Education (RC) & & & 2 & 0.000 & 1.000 & & \\
\hline Primary & -0.110 & 0.077 & 1 & 0.153 & 0.896 & 0.770 & 1.042 \\
\hline Secondary and higher & -0.449 & 0.086 & 1 & 0.000 & 0.638 & 0.539 & 0.756 \\
\hline \multicolumn{8}{|l|}{ Occupation of husband } \\
\hline Unemployed (RC) & & & 4 & 0.001 & 1.000 & & \\
\hline Farmer & 0.426 & 0.129 & 1 & 0.001 & 1.531 & 1.190 & 1.971 \\
\hline Labor & 0.485 & 0.126 & 1 & 0.000 & 1.623 & 1.268 & 2.079 \\
\hline Business or service & 0.358 & 0.125 & 1 & 0.004 & 1.430 & 1.120 & 1.826 \\
\hline Others & -0.110 & 0.457 & 1 & 0.809 & 0.896 & 0.366 & 2.192 \\
\hline
\end{tabular}




\begin{tabular}{|c|c|c|c|c|c|c|c|}
\hline \multicolumn{8}{|l|}{ Household size } \\
\hline 1 member $(\mathrm{RC})$ & & & 3 & 0.000 & 1.000 & & \\
\hline 2 members & 0.321 & 0.339 & 1 & 0.344 & 1.378 & 0.710 & 2.677 \\
\hline 3-4 members & -0.042 & .331 & 1 & 0.899 & 0.959 & 0.502 & 1.833 \\
\hline 5 and more members & -0.292 & .331 & 1 & 0.377 & 0.746 & 0.390 & 1.429 \\
\hline \multicolumn{8}{|c|}{ No. of Children aged under 5 in household } \\
\hline No child (RC) & & & 3 & 0.000 & 1.000 & & \\
\hline 1 child & -0.106 & .048 & 1 & 0.028 & 0.900 & 0.819 & 0.989 \\
\hline 2 children & -0.361 & .081 & 1 & 0.000 & 0.697 & 0.595 & 0.817 \\
\hline 3 and more children & -0.623 & .180 & 1 & 0.001 & 0.536 & 0.377 & 0.764 \\
\hline \multicolumn{8}{|l|}{ Wealth index } \\
\hline Poor (RC) & & & 2 & 0.079 & 1.000 & & \\
\hline Middle & -0.119 & .054 & 1 & 0.028 & 0.888 & 0.798 & 0.988 \\
\hline Rich & -0.085 & .061 & 1 & 0.166 & 0.919 & 0.815 & 1.036 \\
\hline \multicolumn{8}{|c|}{ Land ownership of household } \\
\hline No land (RC) & & & 2 & 0.031 & 1.000 & & \\
\hline Less than 1 Acre & 0.131 & .051 & 1 & 0.011 & 1.140 & 1.031 & 1.260 \\
\hline 1 acres and more & 0.034 & .065 & 1 & 0.599 & 1.035 & 0.911 & 1.175 \\
\hline \multicolumn{8}{|c|}{ Livestock ownership of household } \\
\hline No $(\mathrm{RC})$ & & & & & 1.000 & & \\
\hline Yes & 0.764 & .060 & 1 & 0.000 & 2.148 & 1.909 & 2.416 \\
\hline \multicolumn{8}{|l|}{ NGO membership } \\
\hline No (RC) & & & & & 1.000 & & \\
\hline Yes & 0.457 & .044 & 1 & 0.000 & 1.579 & 1.449 & 1.720 \\
\hline \multicolumn{8}{|l|}{ Religion } \\
\hline Muslim (RC) & & & & & 1.000 & & \\
\hline Non-muslim & 0.320 & .068 & 1 & 0.000 & 1.378 & 1.205 & 1.575 \\
\hline
\end{tabular}

$\mathrm{RC}=$ Reference category.

The result of logistic regression analysis shows that all variables are found to have significant effects on women participation in labor force. Women's age has a strong positive association with women participation in labor force. Table 2 demonstrates that women with age 35-39, 40-44 and 45-49 are 1.277, 1.295 and 1.283 times more likely to have participation in labor force, respectively as compared to the women who belongs to age less than 35 . This is because the early married women (age 15- less than 35) are dependent on their husbands and in the most cases, they are fully engaged with birth and take care of children and other domestic works. The result also portrays that widowed and divorced or separated women are 1.326 and 2.629 times more likely to participate in labor force as compared to currently married women. Because of that widowed and divorced or separated women are main income earner in the family in the most of cases. 
The logistic model illustrates (Table 2) that women's education is negatively significant with women participation in labor force. Increased women's education level, women participation in labor force is gradually decreased. It is observed that women with primary and secondary education are 0.831 and 0.748 times less likely to participate in labor force as compared to women who has no education. It is noted that women's higher education has no significant $(\mathrm{p}>0.10)$ effects on women participation in labor force. This can be explained by the fact that there is not enough respectable job available for educated women and some cases, educated women are less interested to participate in job for better take care of their children and family in rural Bangladesh.

The study reveals that women whose household heads belong to age 35-44 are 1.149 times more and households' head belongs to age 54-59, and age 60 and above are 0.784 and 0.762 times less likely to participate in labor force respectively as compared to the household's head who belongs to age less than 35 . The household's head who belongs to age 45-54 does not have significant impact ( $p>0.10$ ) with women participation in labor force. It is also found that the women with secondary or higher educated household's head are 1.290 times more likely to participate in labor force as compared to women with non-educated household's head. The households head with primary education has no significant $(\mathrm{p}>0.10)$ effect on women participation in labor force.

The result of logistic model portrays that women with secondary or higher educated husband are 0.638 times less likely to participate in labor force as compared to women with non-educated husband. Women with primary educated husband have no significant ( $>0.10)$ association with women participation in labor force. The multivariate analysis shows that husband's occupation is strongly associated with women participation in labor force. The odd ratio indicates that women whose husband's occupation is farmer, labor and business or service are 1.531, 1.623 and 1.430 times more likely to participate in labor force. Women whose husband's occupation is others (religious leader, beggar, etc.) are not significant $(\mathrm{p}>0.10)$ with women participation in labor force.

The result illustrates that household size is negatively significant with women participation in labor force. The result of logistic model portrays that number of children under age 5 have a negative significant association with women participation in labor force. The odds ratio shows that with increased number of children under five, women participation in labor force is gradually decreased.

There is no significant difference $(\mathrm{p}>0.10)$ between poor and rich class women. The odds ratio mentions that middle class women are 0.888 times less likely to participate in labor force $(\mathrm{p}<0.05)$ as compared to poor women. It is expected that poor women participated 
in labor force to increase the family income. The study reveals that land ownership of household has significant association ( $p>0.05$ ) with women participation in labor force. It is observed that women with less than 1 acre's land ownership household are 1.140 times more likely to participate in labor force as compared to women with no landowner household. The result of logistic model displays in the Table 2 that livestock ownership of household has a strong positive significant $(\mathrm{p}<0.001)$ relationship with women participation in labor force. The odds ratio shows that women whose household has own livestock are 2.148 times more likely to participate in labor force as compared to women whose household has no livestock ownership. Women with NGO membership are 1.579 times more likely to participate in labor force as compared to women without NGOmembership. This may happen because women with NGO membership are involved in various income generating activities (IGAs) through microcredit loan and other interventions. The logistic model also portrays that non-Muslim women are 1.378 times more likely to participate in labor force as compared to Muslim women.

From the results of logistic regression analysis, it is concluded that women's age has a strong positive association with women participation in labor force. Widowed and divorced/separated women participated more times in labor force as compared to married women. It is also found that with increased education level of women and their husband, women participation in labor force is decreased, but with increased education level of household head, women participation in labor force has gradually increased. Husband's occupation is also a strong significant determinant of women participation in labor force. Women with middle economic status are less interested in employment as compared to the women of poor economic status, but rich economic status has no significant impact on women participation in labor force. The result also shows that with increased household size and number of children under five, women participation in labor force is decreased. Again, with increased land ownership of household, livestock ownership of household and NGO membership, women participation in labor force is highly increased. Proper initiative need to be taken to increase women employment status in rural Bangladesh so that they can contribute to household income and poverty reeducation of household as well as socio-economic development of society.

\section{Acknowledgements}

The authors express their gratitude and thanks to Professor Dr. Soma Chowdhury Biswas, Department of Statistics, University of Chittagong for her valuable criticisms during the preparation of this paper. 


\section{References}

Aly, Y.H. and I.A. Quisi.1996. Determinants of women labor force participation in Kuwait: A logit analysis. Middle East Bus. Econ. Rev.8: 2.

Amin, S. 2005. Selective inclusion or active discrimination? Women and Labor Market in Bangladesh, Chapter 12, Emerging Issues in Bangladesh Economy: A Review of Bangladesh's Development 2005-06, Dhaka.

Amin, S. 1994. The poverty-purdah trap in rural Bangladesh. Paper presented at the IUSSP's Seminar on Women, Poverty, and Demographic Change, Oaxaca, Mexico.

Atieno, R. 2006. Female participation in the labor market. The case of the informal sector in Kenya. University of Nairobi AERC Research Paper No. 157.

Babalola, S.J. and M. Akor. 2013. An empirical analysis of labor force participation of married women in Adamawa State, Nigeria. J. Emerg. Trends Econ. Manag. Sci. 4(1): 1-7.

Bbaale, E. and P. Mpuga. 2011. Female education, labor force participation and choice of the employment type: evidence from Uganda. Int. J. Econ. Bus. Model. 2(1): 29-41.

BBS. 2018. Labor Force Survey (LFS) 2016-17.Bangladesh Bureau of Statistics, Ministry of Planning, Government of the People's Republic of Bangladesh.

BBS. 2012. Report of the Bangladesh Population and Housing Census 2011.Bangladesh Bureau of Statistics, Ministry of Planning, Government of the People's Republic of Bangladesh.

BDHS. 2014. Bangladesh Demographic and Health Survey 2014.National Institute of Population Research and Training (NIPORT), Mitra and Associates, and Macro International, Dhaka, Bangladesh and Calverton, Maryland, USA.

Chadwick, B.A. and L.T. Brent.1993. Religiousity and delinquency among LDS adolescents. J. Sci. Study Relig. 32(1): 51-67.

Che, G.N. and F. Sundjo. 2018. Determinants of female labor force participation in Cameroon. Int. J. App. Econ. Finance Acc. 3(2): 88-103.

Devereux, P. 2004. Changes in relative wages and family labor supply. J. Hum. Resour. 39(3): 696722.

Faridi, Z., I. Sharif, and M. Anwar. 2009. The socioeconomic and demographic determinants of women work participation in Pakistan: Evidence from Bahawalpur district. South Asian Stud. 24(2): 351-367.

Fontana, M. and C. Paciello. 2010. Gender Dimensions of Rural and Agricultural Employment: Differential pathways out of Poverty: A Global Perspective. Part I. In: Gender Dimensions of Agricultural and Rural Employment: Differentiated Pathways out of Poverty. Rome: $\mathrm{FAO} / \mathrm{IFAD} / \mathrm{ILO}$.

Grantham, G. 2012. Occupation, Marital Status and Life-Cycle Determinants of Women's Labor Force Participation in Mid-nineteenth-Century Rural France. EHES Working Paper No. 22.

Guiso, L., P. Sapienza, and L. Zingales. 2003. Peoples opium?. Religion and economic attitudes. J. Monet. Econ. 50(1): 225-282.

Iweagu, H., D.N. Yuni, C. Nwokolo and A. Bulus. 2015. Determinant of female labor force participation in Nigeria. The rural/urban dichotomy. J. Econ. Sustain. Dev. 6(10): 212-219.

Kalenkoski, S., D.S. Ribar and L.S. Stratton. 2009. The influence of wages on parents' allocation of time to child care and market work in the United Kingdom. J. Popul. Econ. 22(2): 399-419.

Khandker, S. 1987. Labor Market Participation of Married Women in Bangladesh. Rev. Econ. Stat. 69(3).

Lisaniler, F.G. and F. Bhatti. 2005. Determinants of female labor force participation: A study of North Cyprus. Rev. Soc. Eco. Bus. Stud. 5(6): 209-226.

Maglad, N.A. 1998. Female labor supply in Sudan. Department of Economics, Gezira University Sudan. African Economic Research Consortium paper 30. March. 
Mammen, K., and C. Paxson. 2008. Women's Work and Economic Development. J. Econ. Perspect. 14(4): 141-164.

Mincer, J. 1962. Labor Force Participation of Married Women: A Study of Labor Supply. In H. G. Lowis (ed.) Aspects of Labor Economics", Princeton, N. J.: Princeton University Press.63-97.

Mlatsheni, C. and M. Leibbrandt. 2001. The role of education and fertility in the participation and employment of African women in South Africa. Development Policy Research unit: Working Paper No. 01: 54.

Oluwasey, S.D. 2013. Determinants of female labor force participation in Switzerland. Eur. J. App. Soc. Sci. Res. 1(2): 58-66.

Rahman, K.M.M. 2013.Women in Labor Force. Accumulation and Alienation: State of Labor in Bangladesh 2013.Shrabon Prokashani. Dhaka, Bangladesh.

Rahman, R.I. 2006. Gender and Labor Market: Trends and determinants. Working paper for The World Bank, Dhaka.

Rai, S. 2017. Determinants of Rural Female Work Participation in West Bengal - A Study of North Bengal Region. ZENITH Int. J. Multidiscip. Res. 7(11): 173-184

Roy, A., D.Z. Ethen, R.A.Z. Tama and I.A. Begum. 2015. Women labor participation in rice production in some selected areas of Thakurgaon district. Res. Agric. Livest. Fish 2(2): 239-246.

Sackey, H. A. 2005. Female labor force participation in Ghana: The effects of education. Nairobi: African Economic Research Consortium.

(Revised copy received on 27.06.2020) 